\title{
Islamic Micro Finance Melati: Upaya Penguatan Permodalan bagi Pedagang Pasar Tradisional
}

\author{
Sabirin \\ Universitas Padjadjaran Bandung \\ email: sabirin_bisa@yahoo.com \\ Dini Ayuning Sukimin \\ Universitas Padjadjaran Bandung \\ email : diniayuning.rs@gmail.com
}

\begin{abstract}
The purpose of this research is to examines Islamic Micro Finance Melati (Melawan Rentenir) in helping traders in traditional markets to avoid the practice of loan sharks. This article uses descriptive explorative approach by analyzing the right strategy in the management of islamic micro finance institution targeting especially for traders in traditional market in Indonesia. From this study obtained the following conclusions. First, the design of Islamic Micro Finance Melati in order to create an easy Islamic microfinance institution in providing capital financing is very suitable in overcoming the practice of loan shark. Second, working capital is channeled using a system of cooperation whereby the trader is obliged to return the principal and profit share of the profit. Third, the organizational structure and management patterns that are not complicated will make Islamic Micro Finance Melati is easy to realize. Fourth, the existence of Islamic Micro Finance Melati can be an example for other Islamic microfinance institutions in managing management strategy so that sharia microfinance institution can be the main choice for micro business actors.
\end{abstract}

Keywords: traditional market traders; moneylenders; Islamic micro finance.

Abstrak: Tujuan penelitian ini untuk mengkaji Islamic Micro Finance Melati (Melawan Rentenir) dalam membantu pedagang di pasar tradisional dari praktik rentenir. Penelitian ini menggunakan pendekatan eksploratif deskriptif dengan menganalisis strategi yang tepat dalam pengelolaan lembaga keuangan mikro syariah yang menyasar para pedagang di pasar tradisional di Indonesia. Dari penelitian ini diperoleh kesimpulan: Pertama, desain Islamic Micro Finance Melati dalam rangka menciptakan lembaga keuangan mikro syariah yang mudah dalam memberikan pembiayaan permodalan sangat cocok dalam mengatasi praktik rentenir. Kedua, modal kerja yang disalurkan menggunakan sistem kerjasama dimana pedagang wajib mengembalian pokok dan bagi hasil dari keuntungan. Ketiga, struktur organisasi dan pola pengelolaan yang tidak rumit akan membuat Islamic Micro Finance Melati ini mudah untuk direalisasikan. Keempat, keberadaan Islamic Micro Finance Melati dapat menjadi contoh bagi lembaga keuangan mikro syariah lainnya dalam pengelolaan strategi pengelolaan sehingga lembaga keuangan mikro syariah dapat menjadi pilihan utama bagi pelaku usaha mikro.

Kata Kunci: pedagang pasar tradisional; rentenir; Islamic micro finance.

Economica: Jurnal Ekonomi Islam - Volume 8, Nomor 1 (2017) 
Sabirin, Dini Ayuning Sukimin

\section{Pendahuluan}

Lembaga sektor keuangan sangat dibutuhkan keberadaannya guna mendukung permodalan dalam sektor riil. Salah satunya adalah dalam bentuk konsep perbankan baik yang berbentuk konvensional maupun yang berprinsip syariah. Namun konsep perbankan ini sendiri belum sepenuhnya mampu menyentuh Usaha Mikro Kecil Menengah (UMKM) seperti para pedagang di pasar tradisional atau para pelaku ekonomi kerakyatan. Ketidakmampuan perbankan menyentuh sektor ini menyebabkan pelaku pasar tradisional kekurangan sumber permodalan. Padahal permodalan dalam usaha sangat penting karena kekurangan modal dapat membatasi ruang gerak aktivitas usaha. Bagi pedagang di pasar tradisional, keterbatasan modal dapat menyebabkan terjadinya kesulitan untuk mencapai tingkat pendapatan yang optimal guna menjaga kelangsungan hidup usahanya. Kebutuhan permodalan yang tidak terpenuhi itu pun pada akhirnya telah mengurangi keberadaan jumlah pasar tradisional di Indonesia. Pada tahun 2007 pasar rakyat berjumlah 13.550 pasar. Pada 2009 jumlahnya turun menjadi 13.450 pasar, dan pada 2011 berjumlah 9.950. Dan berdasarkan hasil survei Kementrian Perdagangan tahun 2012, jumlah pasar tradisional di Indonesia mengalami penurunan menjadi 9.559 pasar (Esthi 2014). Inilah yang menyebabkan terjadinya ketimpangan pasar dalam ekonomi yang kemudian menciptakan pengangguran-pengangguran baru di Indonesia.

Semestinya para pedagang di pasar tradisional yang menjadi cerminan ekonomi kerakyatan mendapat kemudahan dalam mengakses sumber permodalan yang dapat menunjang kelancaran dalam usaha mereka. Namun terbatasnya akses pembiayaan modal dengan bunga rendah bagi para pedagang telah menjadi faktor semakin terpuruknya jumlah pasar tradisional di Indonesia, selain faktor-faktor lain, seperti buruknya citra pasar tradisional di kalangan masyarakat, kondisi pasar yang memprihatinkan, sarana yang tidak lengkap, kualitas produk yang tidak standar serta suasana yang tidak nyaman. 
Pemerintah sebenarnya sudah berupaya untuk mengatasi hal ini, misalnya dengan mengeluarkan jenis pembiayaan Kredit Usaha Rakyat (KUR). Namun karena beberapa faktor, seperti rumitnya administrasi yang pada akhirnya membuat pedagang pasar tradisional ini justru lebih memilih lembaga keuangan informal, yang justru sebenarnya jauh lebih mahal daripada lembaga keuangan formal (Hidayati 2014). Lembaga keuangan informal yang saat ini banyak ditemui di pasar tradisional adalah rentenir (moneylender).

Menurut M. Ishak, tingginya kebutuhan masyarakat akan dana atau pembiayaan terutama untuk modal usaha, membuat rentenir masih akan tumbuh pesat di sepanjang tahun 2014. Selain karena mudah mencairkan dananya juga karena proses administrasi yang lebih mudah jika dibandingkan dengan mengajukan pembiayaan di perbankan (Simamora 2014).

Rentenir dalam pandangan masyarakat Indonesia mempunyai stigma yang negatif, karena mengandung usur bunga atau riba. Hal ini senada dengan yang disampaikan oleh Plato (427-347 SM) dalam bukunya Laws yang mengutuk bunga dan memandangnya sebagai praktik yang zalim. Dalam Islam, transaksi keuangan dengan sistem rente adalah salahsatu transaksi yang diharamkan. Larangan terhadap transaksi ini secara jelas disebutkan Allah swt dalam firman-Nya:

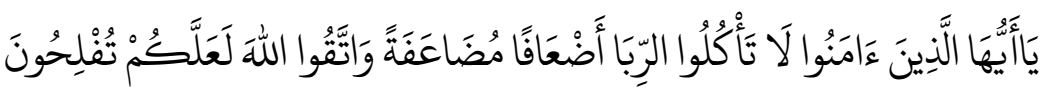

"Wahai orang-orang yang beriman, janganlah kalian memakan riba dengan berlipat ganda dan bertakwalah kalian kepada Allah supaya kalian mendapat keberuntungan". (QS. Ali Imran [3]: 130)

Terlepas dari berbagai stigma negatif tersebut, jasa rentenir justru masih dibutuhkan oleh masyarakat terutama pedagang kecil yang membutuhkan modal untuk usaha yang digelutinya. Kelebihan meminjam dari rentenir adalah karena persyaratan yang mudah, kecepatan dalam 
Sabirin, Dini Ayuning Sukimin

pencairan dana, dan tidak adanya jaminan dalam bentuk apa pun. Keunggulan yang ditawarkan oleh rentenir menjadikan transaksi ini masih terus berkembang hingga sekarang dan membuat keberadaan lembaga keuangan lain seperti bank umum, bank swasta, termasuk lembaga keuangan syariah dan lembaga keuangan mikro secara total belum mampu menghilangkan keberadaan transaksi rente di Indonesia. Selain itu, praktik rentenir ini selalu menyasar kelompok masyarakat menengah ke bawah. Karena mereka adalah kelompok yang paling rentan disebabkan tingkat pendidikan serta kesulitan aksesibilitas mereka terhadap lembaga keuangan yang formal sehingga mudah diperdaya. Rentenir itu seolah-olah menawarkan kemudahan padahal pada hakikatnya sangat merugikan. Akibatnya hidup mereka tidak berubah, seolah-olah berusaha tapi tidak ada peningkatan kesejahteraan. Karena itulah praktik pinjaman rente ini harus dilawan.

Masih diterimanya transaksi rente sebagai solusi permodalan oleh pedagang di pasar tradisional haruslah menjadi perhatian semua pihak. Pembiayaan permodalan melalui jasa rentenir ini hanyalah memberikan solusi untuk jangka pendek. Modal memang mudah didapat, tapi dalam jangka panjang pedagang dihadapkan pada bunga yang tinggi dari pinjaman dan akan menjerat kondisi keuangan mereka.

Di berbagai tempat, banyak para pedagang yang berusaha menjadikan rentenir sebagai sumber permodalan mereka, tetapi hal itu justru memperburuk kondisi mereka. Para pedagang pasar tradisional di Tangerang, misalnya, dengan nilai bunga pinjaman yang tinggi membuat para pedagang terus merugi. Di kecamatan Sudimoro yang berbatasan dengan kabupaten Trenggalek, pasar di kecamatan Bandar dan Tegalombo yang berbatasan dengan kabupaten Ponorogo dan pasar di kecamatan Donorojo yang berbatasan dengan Jawa Tengah, masih banyak praktik simpan pinjam rentenir yang berkedok KSP (Koperasi Simpan Pinjam). 
Bunga yang ditetapkan sangat tinggi rata-rata lebih dari 10\%, dan jika para pedagang terlambat membayar akan dikenakan denda (Navis 2015).

Hal ini tentu tidak boleh dibiarkan begitu saja dan solusi atas permasalahan ini mutlak diperlukan. Sebagai negara dengan penduduk mayoritas muslim, sudah seharusnya lembaga keuangan mikro berbasis syariah memberikan solusi atas persoalan sumber permodalan. Sehingga kebiasaan buruk pedagang dalam mengajukan kesulitan permodalan yang dihadapi kepada para lintah darat sedikit demi sedikit dapat berkurang dan bahkan pada akhirnya dapat hilang.

Atas dasar tersebut, maka perlu dilakukan analisa lebih mendalam agar kemudian tercipta solusi berupa sistem baru yang sesuai dengan prinsip syariah dan dapat menggantikan sistem rentenir yang telah berkembang. Konsep baru tersebut juga diharapkan dapat membuat lembaga keuangan mikro syariah terselenggara dengan optimal sebagai upaya untuk menjadi sumber permodalan yang berkesinambungan bagi pesertanya. Pola pikir yang selama ini yang menyatakan bahwa lebih mudah berurusan dengan rentenir atau jenis lainnya harus diubah. Lembaga keuangan mikro syariah harus mampu mendorong serta menyokong para pelaku usaha mikro, kecil dan menengah, seperti para pedagang di pasar tradisional, agar mereka tetap mampu berkarya dan produktif. Sementara bagi lembaga keuangan mikro syariah itu sendiri, diharapkan mampu meningkatkan daya saing serta mempertahankan eksistensinya sebagai lembaga keuangan mikro syariah yang terdepan.

Saat ini lembaga keuangan mikro syariah di Indonesia terus berkembang. Hal ini seiring dengan lahirnya kebijakan-kebijakan pendukung lainnya. Namun perkembangan lembaga keuangan mikro syariah ini masih belum mampu mengungguli perkembangan industri keuangan non-bank syariah lainnya, seperti asuransi syariah, pasar modal syariah, sukuk, serta reksadana syariah. Oleh karena itu, perlu terobosan baru dalam pengelolaan lembaga keuangan mikro syariah agar lebih produktif dan mampu 
Sabirin, Dini Ayuning Sukimin

memperluas jangkauan dari penerima manfaat atas dana yang akan digulirkan.

Sesuai dengan fenomena yang dijabarkan di atas, maka sangat penting bagi lembaga keuangan mikro syariah untuk memperluas jangkauan mereka dengan melakukan upaya penjemputan bola, melalui beberapa hal seperti meringankan kerumitan administrasi yang selama ini masih menjadi kendala. Lembaga keuangan mikro syariah harus mampu menyasar para pelaku usaha mikro, kecil, dan menengah, khususnya para pedagang di pasar tradisional yang membutuhkan sumber permodalan dalam melakukan aktivitas perdagangan atau usaha mereka. Pemerintahan Kota Bandung, misalnya, memiliki program pemberian kredit lunak kepada yang membutuhkan tanpa bunga yaitu fasilitas kredit Melati (Melawan Rentenir). Konsep fasilitas ini masih merupakan produk perbankan yang dalam pelaksanaannya dilaksanakan oleh PD. BPR Kota Bandung (Bandung 2015).

Tulisan ini akan membahas tentang Islamic Micro Finance Melati (Melawan Rentenir) yang berdasarkan pada prinsip-prinsip syariah. Yang menjadi fokus utama tulisan ini adalah untuk mengetahui: (1) model atau skema rentenir yang berkembang di masyarakat saat ini?, (2) faktor-faktor yang memengaruhi pedagang di pasar tradisional dalam memilih sistem rente?, dan (3) pola kerja Islamic Micro Finance Melati (Melawan Rentenir) dalam membantu pedagang di pasar tradisional agar terhindar dari praktik rentenir.

\section{Landasan Teori}

\section{Lembaga Keuangan Mikro Syariah}

Lembaga keuangan mikro syariah adalah kelompok swadaya masyarakat sebagai lembaga ekonomi rakyat yang berupaya mengembangkan usaha-usaha produktif dan investasi dengan konsep utamanya adalah sistem bagi hasil untuk meningkatkan kualitas ekonomi pengusaha kecil dalam upaya pengentasan kemiskinan (Abidin 2005). 
Produk-produk lembaga keuangan mikro syariah ini bermacam-macam dan memang disediakan untuk masyarakat, misalnya pembiayaan yang diberikan kepada sektor pertanian, industri, perdagangan barang dan jasa, koperasi, pedagang kecil dan lainnya. Pembiayaan yang diberikan memiliki tujuan untuk mengembangkan dan meningkatkan produktivitas para nasabah atau pesertanya.

Saat ini banyak bermunculan LKM-LKM dengan sistem syariah. Perbedaan mendasar Lembaga Keuangan Mikro Syariah (LKMS) dan LKM konvensional adalah pada sisi akad dan transaksi yang digunakan. LKM dengan sistem syariah memiliki potensi untuk dikembangkan melalui bentuk-bentuk kegiatan pembiayaan Usaha Mikro Kecil dan Menengah (UMKM) dengan menggunakan sistem profit sharing, karena itu penting untuk membuat LKMS ini untuk terus berkembang.

LKMS harus tetap berkembang karena beberapa alasan (PINBUK 2004). Pertama, pembangunan nasional harus dipercepat. Kedua, lebih dari 98\% dari struktur pengusaha nasional adalah usaha mikro yang salah satu faktor kesulitannya adalah masalah permodalan, sementara kurang mengenal bank atau lembaga keuangan dan atau sulit mengaksesnya. Ketiga, bank segan "menyentuh" usaha mikro, karena biaya bank (over head cost) "terlalu mahal" untuk pembiayaan usaha kecil. Keempat, sebagian besar penduduk golongan ekonomi lemah dan tertinggal terjerat rentenir dengan prosedur yang gampang dan sederhana, namun memberatkan akibat pembebanan bunga pinjaman yang besar. Untuk itu, LKMS diperlukan sebagai counter terhadap praktik para rentenir tersebut.

\section{Model dan Skema Pinjaman Rentenir}

Rentenir secara umum digambarkan dengan orang atau kelompok yang mempunyai pekerjaan meminjamkan uang (atau juga dalam bentuk barang) kepada orang lain yang memerlukannya dengan imbalan bunga tertentu yang telah ditetapkan oleh si renternir. Hubungan antara rentenir dengan

Economica: Jurnal Ekonomi Islam - Volume 8, Nomor 1 (2017) 
peminjam, biasanya cukup dekat, karena proses pembayaran cicilan pinjaman dipungut sendiri oleh rentenir (atau orang suruhannya) dan dilakukan setiap hari (Muhammad 2000).

Operasional rentenir ini setiap hari melakukan penagihan yang dilakukan oleh petugas (atau pemilik modal) dengan cara mendatangi rumah-rumah atau tempat usaha secara langsung. Rentenir terdiri dari dua jenis, yaitu rentenir perorangan dan rentenir yang mengatasnamakan lembaga. Rentenir jenis pertama biasanya memiliki kedekatan lebih dengan nasabahnya. Proses pinjaman yang terjadi biasanya rentenir tidak secara langsung menawarkan pinjaman kepada calon nasabahnya, namun calon nasabah yang memerlukan yang secara langsung mengajukan peminjaman kepada rentenir. sedangkan rentenir jenis kedua biasanya menggunakan nama koperasi sebagai landasan aktivitasnya, padahal bukan seperti itu yang dimaksud dengan koperasi. Rentenir jenis ini menawarkan jasa pinjaman secara langsung kepada calon nasabahnya.

Dalam memberikan fasilitas pinjaman kepada nasabah, rentenir memberikan syarat yang sangat mudah. Pada praktiknya, biasanya yang diminta hanya KTP tanpa memerlukan syarat-syarat lain sebagaimana yang diminta oleh lembaga keuangan, baik lembaga keuangan konvensional maupun lembaga keuangan syariah. Faktor kemudahan inilah yang kemudian menjadi alasan mengapa praktik ini masih ada dan tetap diminati oleh masyarakat. Kepercayaan antar kedua belah pihak menjadi dasar dari pinjamannya. Pemberian pinjaman biasanya cukup dengan mengetahui lokasi rumah peminjam, setelah itu pinjaman sudah dapat dicairkan pada saat pinjaman diajukan.

Lazimnya cara membungakan uang yang dilakukan oleh rentenir terdiri beberapa cara. Cara pertama, bunga dibebankan setiap bulan hingga proses pinjaman berakhir. Besaran bunga bersifat tetap berdasarkan pokok pinjaman awal. Contoh, pinjaman sebesar Rp. 500.000,- dengan bunga sebesar 10\%. Maka uang yang harus dikembalikan adalah Rp. 550.000,- pada 
bulan kedua peminjaman, dengan rincian Rp. 500,000,- pokok pinjaman dan Rp. 50.000,- bunga pinjaman. Jika pokok pinjaman tidak dapat dilunasi pada bulan kedua, maka di bulan selanjutnya bunga pinjaman tetap harus dibayarkan sebesar Rp. 50.000,- ditambah besar pokok yang belum terbayar. Sistem bunga seperti ini masih mengizinkan pokok pinjaman dibayar secara berangsur. Bunga pinjaman yang ditetapkan biasanya 10\% (hasil wawancara, 2016).

Cara kedua, bunga ditetapkan setiap bulan hingga proses pinjaman berakhir. Tingkat bunga bersifat tetap berdasarkan pokok pinjaman ditambah bunga pinjaman jika pada bulan tersebut bunga pinjaman tidak dapat terbayar. Contoh, pinjaman sebesar Rp. 500.000,- dan bunga pinjaman 20\%. Maka uang yang harus dikembalikan di akhir bulan adalah Rp. 600.000,- dengan rincian Rp. 500.000,- untuk pokok pinjaman dan Rp. 100.000,- untuk bunga pinjaman. Pokok pinjaman harus utuh dibayarkan sebesar Rp. 500.000,- tidak bisa diangsur. Ketika pokok pinjaman tidak dapat dibayar maka bunga pinjaman wajib dibayar pada akhir bulan. Jika di akhir bulan bunga pinjaman pun tidak dapat dibayar maka pada bulan selanjutnya bunga pinjaman sebesar $20 \%$ akan dikalikan dengan pokok pinjaman ditambah bunga pinjaman yang belum dibayar. Cara terakhir bunga ditetapkan di awal pinjaman yang bersifat tetap satu kali selama periode pinjaman. Contoh, pinjaman sebesar Rp. 500.000- dengan bunga yang 20\%. Maka selama periode pinjaman, dia harus membayar sebesar Rp 600.000,(hasil wawancara, 2016).

Dalam menerapkan bunga pinjaman ini, rentenir biasanya tidak secara langsung menyampaikan persentase bunga di depan nasabah. Rentenir hanya menyampaikan jumlah pinjaman yang harus dikembalikan. Cicilan pinjaman tersebut biasanya dilakukan setiap hari atau sering juga disebut cicilan harian. Jumlah cicilan bervariasi bergantung dengan kebijakan dari rentenir. Dalam praktiknya biasanya masih ada biaya lain di luar dari bunga pinjaman yang dibebankan kepada peminjam. 


\section{Faktor-faktor yang Memengaruhi Pedagang dalam Memilih Sumber Permodalan dengan Sistem Rente}

Dalam mengambil keputusan untuk menerima atau menolak sebuah pinjaman, seseorang dipengaruhi oleh dua faktor, yaitu faktor internal dan faktor eksternal. Faktor Internal adalah faktor yang muncul dari dalam diri masyarakat, baik itu berupa dorongan untuk memilih maupun menolak sistem rente dalam aktivitas ekonominya. Faktor Eksternal adalah faktor yang muncul dari luar diri subjek, baik itu yang berasal dari rentenir secara langsung maupun dari lingkungan sekitar yang mendukung. Faktor ini dapat berupa dorongan untuk memilih maupun menolak sistem rente dalam aktivitas ekonominya (Lukytawati Anggraeni 2013).

Selain pengaruh faktor internal dan eksternal, terdapat tiga faktor lain yang dapat memengaruhi keputusan seseorang dalam memilih rentenir atau tidak. Faktor tersebut adalah pendidikan formal, pendidikan agama dan tidak adanya alternatif pembiayaan lain yang sesuai dengan syariah. Faktor pendidikan formal memiliki peran membentuk pemikiran rasional dari masyarakat tentang berlakunya sistem bunga. Dari hasil observasi diperoleh data bahwa penerapan bunga dalam setiap pinjaman telah diajarkan sejak di bangku Sekolah Dasar. Secara tidak langsung, pendidikan formal ini memberikan pemahaman kepada masyarakat bahwa memberikan pinjaman dengan kelebihan bunga merupakan suatu hal yang wajar. Sehingga ketika transaksi keuangan di masyarakat menggunakan sistem bunga, maka masyarakat memandang hal tersebut sebagai sesuatu yang wajar.

Faktor pendidikan agama seharusnya dapat berperan dalam memberikan pemahaman terhadap larangan bunga. Pemahaman agama dapat membentuk mental masyarakat untuk menghadirkan rasa takut untuk menjalankan transaksi dengan sistem bunga. Dengan adanya pemahaman larangan riba ini masyarakat seharusnya tidak lagi menggunakan transaksi rente dalam kesehariannya. 
Menurut Indrawati, et. al, (Yovita 2014) dalam kaitannya dengan kasus pedagang di pasar tradisional, faktor kedekatan atau hubungan emosional biasanya sangat memengaruhi keputusan pedagang untuk lebih memilih meminjam kepada rentenir, karena biasanya rentenir langsung turun dan menjangkau para pedagang. Alasan lain mengapa para pedagang di pasar tradisional lebih memilih menggunakan jasa rentenir sebagai sumber permodalannya adalah sebagai berikut:

Pertama, proses yang tidak rumit seperti lembaga keuangan lain. Proses meminjam di rentenir sangat mudah dan cepat. Hanya dalam jangka waktu beberapa hari peminjam (pedagang) sudah mendapatkan pinjaman yang dibutuhkan. Selain itu, untuk meminjam biasanya tidak perlu menyerahkan jaminan, dan persyaratan yang tidak rumit sehingga tentu saja hal ini sangat mempermudah pedagang. Kemudahan yang tidak akan diperoleh pedagang jika meminjam di lembaga keuangan formal seperti bank dan BMT itulah yang akhirnya membuat pedagang lebih menggunakan jasa rentenir sebagai sumber permodalannya. Bunga yang tinggi ketika meminjam di rentenir pun akhirnya tidak dihiraukan oleh pedagang.

Kedua, prosedur pembayaran yang mudah. Rentenir sebagai lembaga keuangan informal keberadaanya cukup dekat dengan para pedagang di sektor informal seperti pedagang pasar. Pedagang yang menggunakan jasa rentenir memperoleh kemudahan dalam hal pembayaran karena sangat mudah dan tidak memberatkan pedagang. Pedagang dapat membayar cicilan pembayaran sesuai dengan kemampuan pedagang. Hal ini juga disebabkan karena pedagang dapat memilih sendiri bunga yang harus dibayarkan kepada rentenir. Jika bunga yang dipilih lebih tinggi, maka cicilan per harinya akan rendah namun jangka waktu pelunasannya semakin lama. Sebaliknya, jika bunga yang dipilih rendah, maka cicilan per harinya tinggi namun jangka waktu pelunasannya semakin cepat. Besarnya bunga pun terbilang relatif tinggi berkisar antara 20\%-40\%. Namun, meskipun bunganya yang 
ditetapkan tinggi, pedagang tidak merasa berat karena cicilan per harinya dapat disesuaikan dengan kemampuannya dan dapat dipenuhi.

Ketiga, kebutuhan modal yang mendesak. Modal merupakan hal yang diperlukan bagi para pedagang untuk menjalankan dan mengembangkan usahanya. Beberapa pedagang kecil yang memerlukan kebutuhan modal yang mendesak dapat menggunakan jasa rentenir untuk memenuhi kebutuhan modalnya. Rentenir sebagai lembaga keuangan informal mampu menyediakan modal dengan proses yang cepat dan tidak rumit. Sehingga pedagang yang memerlukan kebutuhan modal yang mendesak pun dapat memanfaatkan jasa rentenir tersebut agar ketercukupan modalnya dapat terjaga. Apabila pedagang yang membutuhkan modal yang mendesak harus meminjam ke lembaga keuangan formal, tentunya akan mengalami kesulitan terutama untuk memenuhi persyaratan yang ditetapkan dan prosesnya juga panjang. Pedagang pun beralih meminjam kepada rentenir agar kebutuhan modalnya yang mendesak dapat segera terpenuhi.

\section{Metode Penelitian}

Penelitian ini menggunakan pendekatan eksploratif deskriptif dengan menganalisis strategi yang tepat dalam pengelolaan lembaga keuangan mikro syariah yang menyasar khusus bagi para pedagang di pasar tradisional di Indonesia. Peneliti adalah instrument kunci, teknik pengumpulan data dilakukan secara triangulasi (gabungan), analisis data bersifat induktif, dan hasil penelitian lebih menekankan makna daripada generalisasi. Data yang dianalisis tidak untuk menerima atau menolak hipotesis (jika ada). Pada penelitian ini fakta-fakta dianalisis dengan menghubungkan, membandingkan, dan mengembangkan pemikiran sehingga dihasilkan suatu kesimpulan umum yang dapat berlaku lebih umum dalam bidang keilmuan tertentu.

Penelitian ini mengambil data sekunder berupa pendekatan kajian literatur atau studi pustaka. Pendekatan teori atau konsep dilakukan dengan 
merujuk dari beberapa sumber, seperti buku, jurnal ilmiah, portal berita online dan penelusuran literatur online. Semua uraian gagasan yang ada digabungkan dalam satu susunan kerangka pemikiran.

Batasan penelitian ini difokuskan pada pengembangan dan inovasi lembaga keuangan mikro syariah bagi para pedagang di pasar tradisional untuk memperoleh akses permodalan yang mudah. Pengembangan dan inovasi tersebut dibatasi pada operasional lembaga pengelola lembaga keuangan mikro syariah baik dalam penghimpunan (funding) dan penyaluran dana (lending).

Penelitian ini disusun untuk mengekplorasi fenomena yang terjadi dengan memadukan konsep dan operasional lembaga pengelola keuangan mikro syariah sebagai lembaga atau badan yang bergerak di bidang komersial dan sosial keagamaan. Dalam menganalisis permasalahan, terlebih dahulu dilakukan proses analisis terhadap permasalahan kemudian dikaitkan dengan permasalahan yang terjadi di lapangan beserta solusinya dengan menggunakan skema dan konsep yang tepat. Agar memperoleh kebenaran yang ilmiah, penelitian ini dilakukan dengan memerhatikan beberapa tahapan yaitu tahap penyajian bukti atau fakta (skeptik), memerhatikan permasalahan yang relevan (analitik), dan tahap menimbang secara objektif untuk berpikir logis (kritik).

\section{Hasil dan Pembahasan}

\section{Islamic Micro Finance Melati (Melawan Rentenir)}

Keberadaan pengusaha mikro kecil dan menengah, khususnya pedagang di pasar tradisional merupakan wujud kehidupan ekonomi sebagian besar rakyat Indonesia. Posisi ini telah menempatkan pedagang pasar tradisional sebagai hal utama yang harus mendapat perhatian, terutama dalam hal permodalan. Proses pengembangan pedagang pasar tradisional adalah manifestasi dari perkembangan ekonomi yang menjadi sangat penting. Upaya pengembangan dan penguatan potensi pedagang 
pasar tradisional sebagai kelompok ekonomi strategis harus berorientasi pada pemberdayaan, sehingga terbentuk pelaku ekonomi lokal yang mandiri dan kuat melalui Lembaga Keuangan Mikro (LKM) khususnya Lembaga Keuangan Mikro Syariah (LKMS).

Strategi untuk memperkuat permodalan pedagang pasar tradisional harus didasarkan pada pemahaman terhadap karakteristik dan kelemahankelemahan yang melekat di dalamnya. Salah satu alternatif untuk memperkuat posisi pedagang pasar tradisional tersebut adalah dengan mendorong terjadinya kemitraan dan keterkaitan. Diharapkan kemitraan dan keterkaitan akan menghasilkan nilai tambah (ekonomi dan sosial) yang akan memperkuat struktur ekonomi nasional.

Dalam rangka menciptakan kemitraan dan keterkaitan ini, lembaga keuangan mikro syariah dapat ikut aktif dalam memperkuat pedagang pasar tradisional dengan menjadi sumber permodalan bagi mereka. Dalam konteks ini, pihak lembaga keuangan mikro syariah selain memberikan kemudahan dalam mengakses pembiayaan, juga dapat memfasilitasi pemberian informasi pasar, mendorong aliansi strategis, dan memberikan dukungan bantuan manajemen pengelolaan usaha. Harapannya adalah tidak ada lagi pedagang yang mengharapkan sumber permodalan dari rentenir yang hanya mampu menyelesaikan masalah untuk jangka pendek, tetapi setelah itu justru kesejahteraan yang diidam-idamkan tidak kunjung menjadi kenyataan. Langkah ini pun pada akhirnya dapat mempersempit ruang gerak rentenir dan pada akhirnya sistem yang salah ini pun dapat hilang dengan sendirinya.

Islamic Micro Finance Melati adalah sebuah inovasi yang ditawarkan dalam kelembagaan Islamic Micro Finance di Indonesia. Selama ini kita mengetahui pada umumnya lembaga keuangan mikro syariah memiliki aktivitas menjadi sumber permodalan di masyarakat, namun tidak ada nilai tambah atas aktivitas tersebut. Ditambah lagi masalah lembaga keuangan mikro syariah yang belum mampu menjangkau kebutuhan masyarakat 
sehingga masih ada masyarakat khususnya pedagang di pasar tradisional yang memilih rentenir sebagai sumber permodalan mereka. Jika proses ini berjalan terus menerus, maka lembaga keuangan syariah akhirnya akan ditinggalkan.

Melalui Islamic Micro Finance Melati, para peserta atau nasabah (pedagang di pasar tradisional) tidak hanya memperoleh sumber permodalan tapi juga mendapatkan fasilitas lain berupa pemberdayaan dan pendampingan dalam memulai maupun menjalankan usaha mereka. Langkah ini adalah sebuah akselerasi positif dari prinsip operasional Islamic Micro Finance seperti kebanyakan yaitu, mengumpulkan dana dan menyalurkan manfaat.

Gambar 1. Struktur Organisasi Islamic Micro Finance Melati

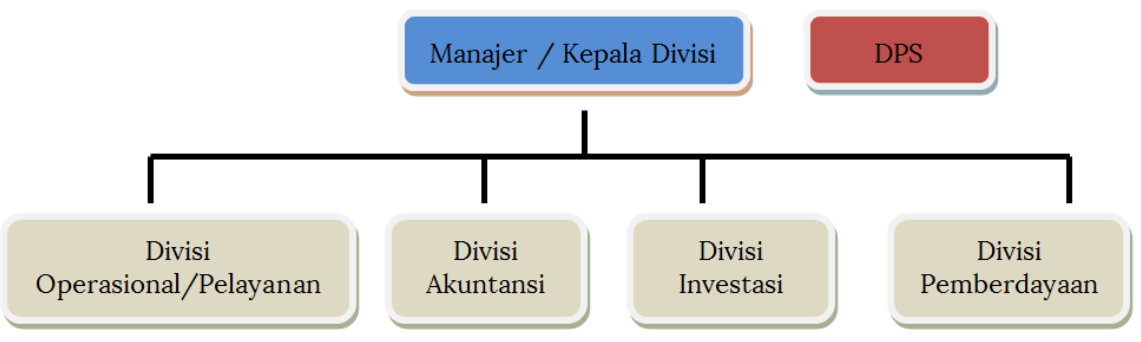

Dalam pengelolaannya, Islamic Micro Finance Melati memiliki empat divisi di bawah manajer atau kepala divisi, yaitu divisi operasional/pelayanan, divisi akuntansi, divisi investasi dan divisi pemberdayaan. Masing-masing divisi sangat penting keberadaannya dalam pengembangan Islamic Micro Finance Melati.

Tugas utama divisi operasional dan pelayanan adalah mencari peserta, yakni pedagang di pasar tradisional. Dari pencarian dan penerimaan peserta inilah nantinya akan diperoleh dana yang siap dicadangkan sebagai tabungan peserta dan dana yang nantinya akan digulirkan bagi peserta sebagai sumber permodalan. Permodalan tidak hanya akan diberikan bagi 
peserta, tetapi yang bukan peserta pun akan dilayani jika ingin mengajukan sumber permodalan.

Divisi akuntansi bertugas mengatur keuangan lembaga. Pengaturan ini diimplementasikan melalui pembedaan rekening untuk masing-masing dana. Pemisahan ini dilakukan berdasarkan karakteristik yang berbedabeda sehingga berbeda pula dalam perlakuan akuntasinya.

Divisi investasi memiliki fungsi untuk melakukan pengembangan dana yang bersumber dari iuran yang telah dibayar oleh peseta dalam bentuk peryertaan langsung atau yang lainnya. Yang menjadi dasar dalam divisi ini adalah investasi yang sehat, berisiko gagal yang kecil dan sesuai dengan prinsip syariah, agar tidak ada kekhawatiran bagi peserta tentang hukumnya (kehalalannya).

Sedangkan divisi pemberdayaan memiliki fungsi menganalisis usaha peserta yang akan dibiayai oleh Islamic Micro Finance Melati, fungsi pendampingan dan fungsi lain yang berkaitan dengan pemberdayaan agar dana yang dikeluarkan tetap produktif dan terjamin kerberlangsungan usahanya.

Gambar 2. Pola Penyaluran Modal Kerja

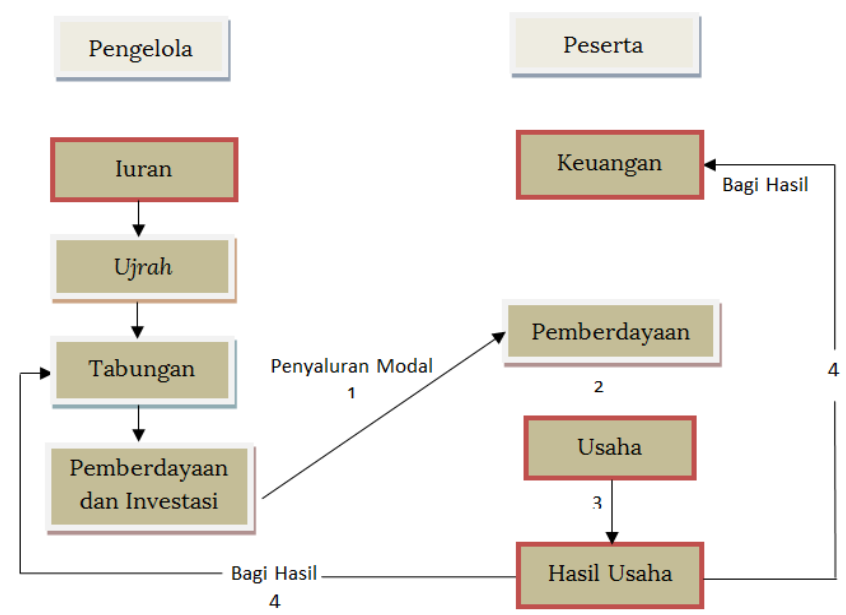


Dana diperoleh melalui iuran yang dilakukan oleh setiap peserta dibagi secara proporsional, yaitu pertama untuk ujrah sebagai sumber pendapatan bagi pengelola, kedua, manfaat yaitu sebagai tabungan yang nantinya akan diperoleh langsung oleh peserta, dan ketiga, dana yang digunakan untuk program pemberdayaan dan investasi yang nantinya bagi hasil yang diperoleh akan menjadi penambah manfaaat bagi peserta.

Iuran yang dibayarkan oleh peserta adalah dengan menggunakan akad hibah. Atas ujrah yang diperoleh antara pengelola dan peserta digunakan akad wakālah bi al-ujrah. Sedangkan atas pemberdayaan yang dilakukan oleh pengelola digunakan akad muḍārabah dan mushārakah dengan prinsip bagi hasil dan akad ijārah dengan prinsip ujrah.

Dana pemberdayaan ini berbentuk pembiayaan yang bebas riba, dimana pengguna dana hanya berkewajiban untuk mengembalikan pokoknya dan bagi hasil terhadap keuntungan usaha sesuai dengan kesepakatan. Pendapatan atas bagi hasil tersebut akan digunakan untuk menambah manfaat yang akan diperoleh peserta. Jangka waktu pembiayaan dimulai dari 12 (dua belas) bulan sampai dengan 60 (enam puluh) bulan dengan platform pembiayaan untuk permulaan maksimal 25 juta dan akan terus meningkat sesuai dengan perkembangan badan pengelola. Pedagang dapat melakukan pengajuan permodalan dengan perorangan maupun berkelompok. Pengajuan kelompok dengan dapat dilakukan dengan minimal empat orang dan maksimal delapan orang.

Setelah usaha berjalan dan mendapatkan keuntungan yang telah dibagi hasil maka keuntungan tersebut sepenuhnya menjadi hak milik peserta. Dengan mekanisme pengelolaan seperti ini, maka tidak hanya pengelola yang aktif untuk mensejahterakan pesertanya tapi peserta sendiri juga aktif untuk tetap produktif, mandiri, dan berdaya dan terbebas dari jeratan rentenir. 
Gambar 3. Pola Penyaluran Investasi

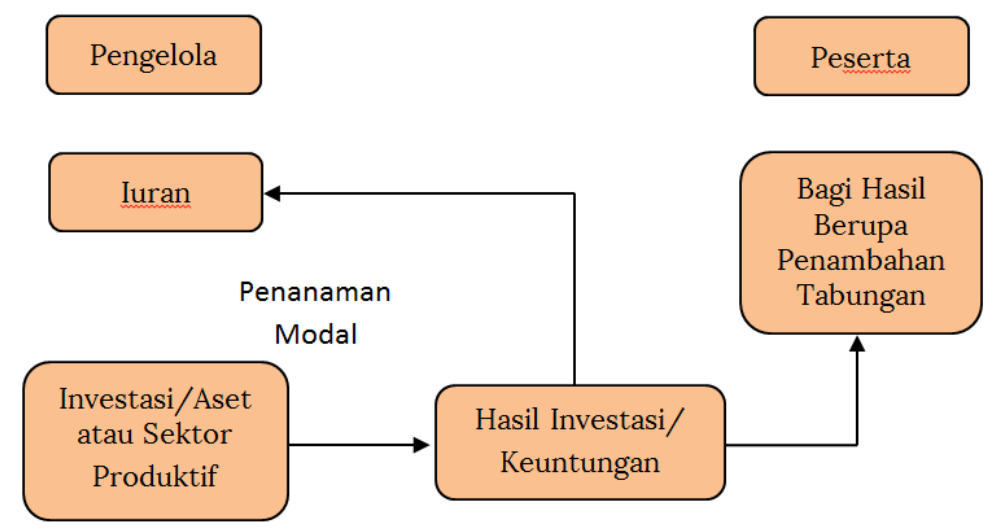

Selanjutnya divisi investasi akan melakukan investasi pada sektorsektor yang dibolehkan oleh syariah. Artinya jenis investasi yang dipilih adalah yang sehat dan aman secara pertimbangan ekonomi juga halal lagi baik berdasarkan pertimbangan syariah. Diantaranya pengelola dapat berinvestasi dengan membeli aset produktif, atau membuat sebuah jenis usaha yang tidak bertentangan dengan syariah. Adapun dari pembelian aset produktif bergerak (seperti mobil, sepeda motor, dan ruko), maka atas manfaat dari aset tersebut akan disewakan sesuai dengan akad ijärah, atas penghasilan yang diperoleh akan digunakan sebagai sumber pendapatan pengelola sendiri dan dibagi hasil untuk penambahan jumlah manfaat atau tabungan yang nantinya akan diperoleh oleh peserta. Dalam hal ini pengelola akan memproduktifkan sendiri dana yang terkumpul dari iuran peserta, kemudian menyalurkan hasil dari bagi hasil kepada peserta dalam bentuk penambahan manfaat yang akan diperoleh oleh peserta.

Kedua pola antara investasi dan pemberdayaan ini harus diatur sebaik mungkin agar operasional Islamic Micro Finance Melati ini dapat terus beroperasi dan pemberdayaan dengan penyaluran harus dalam proporsi yang ideal. Hal ini dimaksudkan agar beban operasional dapat ditutupi dari 
hasil investasi bukan dari iuran peserta sebab dana iuran harus dijaga agar nilainya tidak berkurang.

Adapun pola kerja Islamic Micro Finance Melati secara keseluruhan dapat dilihat dari skema di bawah ini, yang akan menjelaskan secara sederhana proses operasional dari masing-masing divisi dan hubungan antar divisi tersebut.

Gambar 4. Skema Kerja Islamic Micro Finance Melati

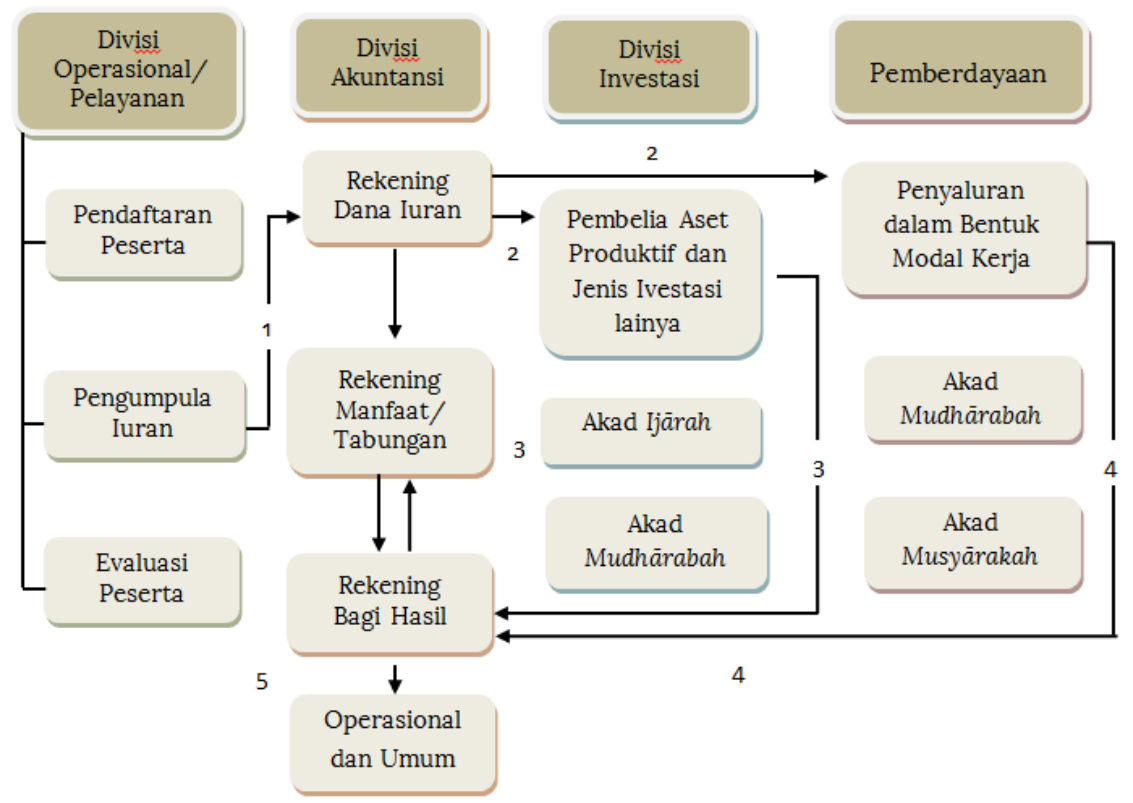

Keterangan:

1. Divisi operasional dan layanan akan mencari peserta (pedagang di pasar tradisional). Setelah melayani pendaftaran peserta, divisi operasional menyusun pembayaran iuran yang akan dibayar oleh setiap peserta. Terhadap iuran yang dibayarkan tersebut, divisi operasional kemudian menyerahkannya ke divisi akuntansi. Setelah dana diterima dari divisi

Economica: Jurnal Ekonomi Islam - Volume 8, Nomor 1 (2017) 
operasional dan pelayanan, divisi akuntansi melakukan pencatatan dan memasukkannya ke dalam rekening yang berbeda.

2. Setelah divisi akuntansi melakukan pemisahan, dana yang masuk dalam rekening dana iuran selain dibagi ke dalam rekening manfaat atau tabungan juga akan diserahkan ke divisi investasi dan pemberdayaan. Kedua divisi inilah yang akan bertanggung jawab penuh terhadap pengembangan dana. Divisi investasi akan melakukan pembelian aset/investasi pada sektor produktif yang nantinya akan dilakukan bagi hasil terhadap keuntungan terhadap investasi tersebut. Divisi pemberdayaan akan memberikan modal kerja kepada peserta dan juga melakukan pedampingan dengan menjadi konsultan terhadap usaha yang dirintis oleh peserta agar jelas secara syariah dan memiliki siklus hidup yang panjang, sehingga cita-cita untuk menciptakan pedagang yang tetap aktif dan terbebas dari jeratan rentenir dapat menjadi kenyataan.

3. Dalam melakukan investasi, Islamic Micro Finance Melati akan menggunakan dua akad, yaitu muḍārabah dan ijārah. Sementara dalam penyaluran permodalan, Islamic Micro Finance Melati menggunakan akad muḍārabah dan mushārakah, berupa pembiayaan penuh dan kemitraan.

4. Dari jenis transaksi tersebut akan menghasilkan bagi hasil dari laba investasi dan usaha serta akan memperoleh pengembalian pokok. Untuk bagi hasil maka akan dimasukan ke rekening bagi hasil, sementara untuk pengembalian pokok akan dimasukan rekening manfaat atau tabungan.

5. Dana dari rekening bagi hasil akan dipergunakan untuk menutupi beban operasional dan mengcover pembiayaan yang tidak dikembalikan akibat gagal bayar. 
Gambar 5. Skema Pemberian Modal Kerja dan Pendampingan

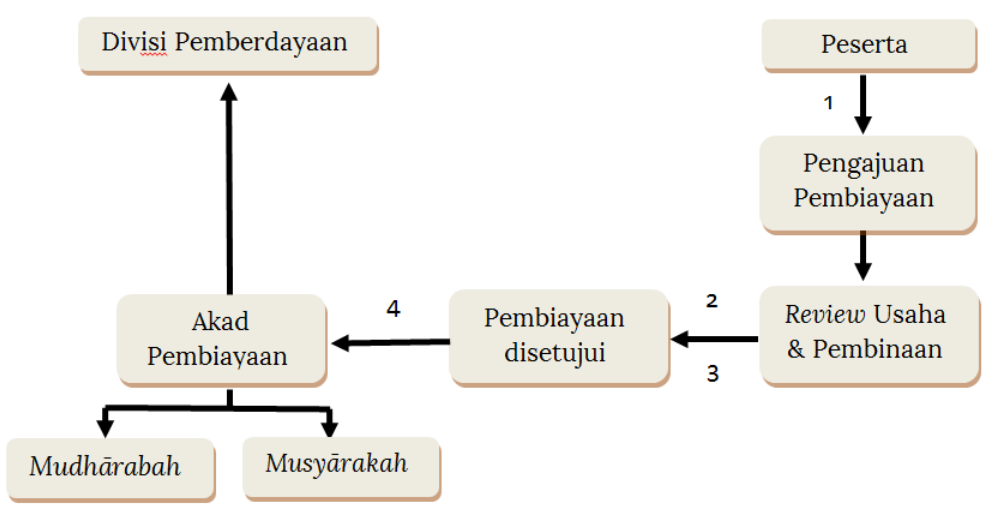

Keterangan:

1. Peserta mengajukan pembiayaan kepada Islamic Micro Finance Melati. Selanjutnya divisi pemberdayaan melakukan review dan pembinaan. Pembinaan yang akan diberikan adalah berupa seminar usaha, coaching klinik, dan konsultasi penyusunan laporan keuangan untuk usaha dagang.

2. Dari pengarahan dan pembinaan yang dilakukan, divisi pemberdayaan akan menghasilkan usaha yang semakin matang dan pribadi yang terbina dari sisi kemampuan mengelola usaha. Setelah itu pembiayaan siap diberikan.

3. Akad yang digunakan adalah akad mudāarabah atau musyārakah sesuai kesepakatan yang wajib dikembalikan dengan sistem bagi hasil.

4. Setelah dana diberikan dan usaha berjalan selanjutnya dilakukan monitoring oleh divisi pemberdayaan secara kontinyu untuk memastikan bahwa usaha yang dijalankan akan memiliki siklus ekonomi yang panjang dan pedagang pun terbebas dari jeratan rentenir. 


\section{Analisis Strategi Pengelolaan Islamic Micro Finance Melati}

Untuk menjamin keberhasilan dan keberlangsungan pengelolaan Islamic Micro Finance Melati maka perlu disusun strategi dalam hal pengelolaan dengan mempertimbangkan faktor internal maupun eksternal. Langkah tersebut dapat dilakukan dengan beberapa hal sebagai berikut :

1. Prosedur pengurusan yang tidak berbelit.

Untuk mengajukan permohonan pembiayaan para nasabah tidak dipersulit dengan berbagai berkas yang harus diisi.

2. Syarat pengajuan yang mudah.

Syarat pengajuan juga mudah, yakni hanya dengan mengisi formulir yang dikehendaki dan petugas akan langsung menindaklanjutinya.

3. Didukung masyarakat.

Pendirian lembaga keuangan mikro syariah ini merupakan bentuk kegiatan yang dilakukan dalam rangka memberikan pendampingan usaha, upaya meningkatkan kesejahteraan, dan kemitraan usaha, yang bertujuan membebaskan pedagang pasar tradisional dari rentenir.

4. Petugas pendampingan yang intensif

Selain memberi dana, petugas juga akan melakukan pendampingan nasabah dalam pengelolaan usahanya, sehingga dapat meminimalisir nasabah yang pailit.

5. Pelayanan yang lebih personalize.

Pelayanan yang diberikan bersifat kekeluargaan antar petugas dengan nasabah maupun antar nasabah dengan nasabah. Hal ini sesuai dengan tradisi masyarakat sub-urban yang bersifat kekeluargaan.

6. Memperbanyak/memperluas spread dan jumlah nasabah.

Strategi ini sangat tergantung pada kekuatan lembaga dalam pengurusan yang tidak berbelit dan mudah, dan di sisi lain peluang 
pembiayaan untuk industri mikro sangat besar. Selama ini potensi kredit mikro belum digarap dengan baik oleh bank umum, sehingga potensi yang besar tersebut masih merupakan lahan "pasar baru" yang dapat dioptimalkan.

7. Melakukan positioning sebagai LKS yang mengutamakan pelayanan.

Memberikan pelayanan yang ramah dan hangat kepada nasabah. Hal ini yang tidak dipunyai oleh bank umum yang sangat sibuk dengan nasabah yang hilir mudik, sehingga aspek kekeluargaan menjadi terbengkalai.

8. Menjual program pemberdayaan masyarakat.

Dengan misi utama untuk mengurangi pedagang dari jeratan rentenir maka peluang untuk terus tumbuh di kalangan pedagang pasar tradisional akan semakin besar.

9. Mengedukasi nasabah.

Mendidik nasabah dengan layanan lembaga keuangan mikro syariah dengan sistem kemitraan merupakan salah satu solusi.

10. Melakukan penetrasi pasar yang lebih gencar.

Selain perlu melakukan edukasi pada calon nasabah, perlu dilakukan strategi jemput bola pada nasabah yang mempunyai waktu terbatas. Dalam hal ini diperlukan sales force yang bertugas memasarkan produk-produk pembiayaan atau produk tabungan guna meningkatkan modal pembiayaan.

11. Pemilihan lokasi yang tepat.

Tempat atau kantor merupakan faktor yang penting dalam pemberian pelayanan kepada nasabah. Lokasi yang dipilih adalah yang dekat dengan nasabah. Dalam hal ini, Islamic Micro Finance Melati ditempatkan di pasar tradisional karena di situlah tempat nasabah berada. Lokasi yang dekat dengan nasabah ini tentu akan 
mempermudah dalam pengawasan, pemberian pemahaman tentang transaksi syariah, dan penagihan. Di samping itu, lokasi yang dekat dengan nasabah dapat menumbuhkan hubungan emosional yang baik antara nasabah dan pengelola.

12. Menambah modal dengan pinjaman modal pemerintah.

Dengan potensi yang masih besar, Islamic Micro Finance Melati perlu mempersiapkan diri sewaktu-waktu terjadi lonjakan nasabah yang mengajukan pembiayaan. Oleh karena itu, diperlukan dana besar untuk menambah permodalan. Dana dari pemerintah sangat mungkin didapatkan, baik dari pemerintah pusat maupun pemerintah daerah karena sebenarnya terdapat dana yang memang dialokasikan untuk pemberdayaan masyarakat. Selain itu dana pemerintah ini tergolong murah dan dapat menjadi solusi yang tepat.

Dengan langkah-langkah di atas dan dengan sinergitas yang baik, maka akan tercipta pedagang di pasar tradisional yang terbebas dari jeratan rentenir. Pola pikir bahwa meminjam pada rentenir jauh lebih mudah pun akan hilang dengan sendirinya. Selain itu akan tercipta lembaga keuangan mikro syariah yang lebih diminati.

\section{Simpulan}

1. Desain Islamic Micro Finance Melati dalam rangka menciptakan lembaga keuangan mikro syariah yang mudah dalam memberikan pembiayaan permodalan ini sangat cocok untuk mengatasi masalah pedagang di pasar tradisional yang banyak terjerat oleh rentenir.

2. Modal kerja yang disalurkan merupakan modal kerja dengan hanya pengembalian pokok dan sistem bagi hasil sehingga peserta (para pedagang di pasar tradisional) yang menggunakan modal ini tidak akan dibebani dengan pengembalian kelebihan karena pinjaman ini bebas dari unsur riba. 
3. Struktur organisasi dan pola pengelolaan yang tidak rumit akan membuat Islamic Micro Finance Melati ini mudah untuk direalisasikan. Peluang besar yang ada akan menjadi keunggulan tersendiri bagi Islamic Micro Finance Melati ini.

4. Keberadaan Islamic Micro Finance Melati ini dapat menjadi contoh bagi lembaga keuangan mikro syariah lainnya, terutama dalam hal pengelolaan strategi pengelolaan, agar lembaga keuangan mikro syariah dapat menjadi pilihan utama bagi pelaku usaha mikro - khususnya para pedagang di pasar tradisional- dalam mencari sumber permodala,.

Dari penelitian ini ada beberapa sasaran yang perlu dikemukakan :

1. Konsep Islamic Micro Finance Melati yang coba dikembangkan ini patut dicontoh oleh lembaga keuangan mikro syariah lainnya. Konsep ini merupakan upaya untuk menjadikan lembaga keuangan mikro syariah menjadi pilihan utama pedagang dalam hal sumber permodalan dan membebaskan para pedagang di pasar tradisional dari praktik lintah darat yang dapat mematikan usaha.

2. Para pedagang hendaknya lebih menyadari kerugian yang akan mereka tanggung jika memilih rentenir sebagai sumber permodalan mereka. Walaupun rentenir memberikan kemudahan dalam peminjaman uang, tapi suku bunga tinggi yang harus mereka tanggung justru akan membuat mereka kesulitan dalam mendapatkan keuntungan.

3. Lembaga keuangan mikro syariah hendaknya melakukan pendekatan kekeluargaan untuk menarik hati para pedagang. Selain itu hubungan emosional yang baik harus mampu dijalin sebagaimana yang dilakukan oleh pelaku jasa rentenir. Pelaku jasa rentenir selalu melakukan interaksi sosial dengan yang meminjam uang. Maka tidak ada salahnya lembaga keuangan mikro syariah mengadopsi cara ini. 
Sabirin, Dini Ayuning Sukimin

\section{Daftar Pustaka}

Abidin, Amir Mu'alim dan M Zainal. 2005. "Profesionalisme Praktisi BMT di Kota Yogyakarta dan Kabupaten Sleman." Millah: Jurnal Studi Agama (Universitas Islam Indonesia) 4 (2): 79-96.

Amalia, Euis. 2009. Keadilan Distributif dalam Ekonomi Islam: Penguatan LKM dan UKM di Indonesia. Jakarta: Rajawali Pers.

Ananda, Fitra. 2011. "Analisis Perkembangan Usaha Mikro dan Kecil Setelah Memperoleh Pembiayaan Mudharabah dari BMT At Taqwa Halmahera di Kota Semarang." Skripsi, Semarang: Universitas Diponegoro.

Bandung, Dinas Komunikasi dan Informatika. 2015. Accessed Juni 6, 2016.

Damsar. 1997. Sosiologi Ekonomi. Jakarta: Rajawali Press.

Djazuli, A. 2006. Kaidah-Kaidah Fikih: Kaidah-Kaidah Hukum Islam dalam Masalah-Masalah yang Praktis. Jakarta: Kencana.

Esack, Farid. 2000. Membebaskan Yang Tertindas. Terj. Watung A. Budiman. Bandung: Mizan.

Esthi, Maharani. 2014. "http://www.republika.co.id." berita/ekonomi/ makro/14/10/02/nct8ag-jumlah-pasar-tradisional-semakin-menurun. Accessed Juni 6, 2016.

Hidayati, Bunga. 2014. "Peran Modal Sosial Pada Kontrak Pinjaman Bank Thithil dan Implikasinya Terhadap Keberlangsungan Usaha (Studi Pada Pasar Blimbing Kota Malang)." Jurnal Ilmiah 2 (1): 1-16.

Kartono, Drajat Tri. 2004. "Pasar Modal Tradisional (Analisis Sosiologi Ekonomi terhadap Rentenir)." Jurnal Sosiologi DILEMA 17, no. 1, 1-9.

Lukytawati Anggraeni, Herdiana Puspitasari, Salahuddin El Ayubbi, dan Ranti Wiliasih. 2013. "Akses UMKM Terhadap Pembiayaan Mikro Syariah dan Dampaknya Terhadap Perkembangan Usaha: Kasus BMT Tadbiirul Ummah, Kabupaten Bogor." Jurnal al-Muzara'ah (Fakultas Ekonomi dan Manajemen Institut Pertanian Bogor) 1 (1): 56-67.

Moleong, Lexy J. 2004. Metode Penelitian Kualitatif. Bandung: Remaja Rosdakarya.

Muhammad. 2000. Lembaga-lembaga Keuangan Umat Kontemporer. Yogyakarta: UII Press. 
Navis, Mar'atus Syawalia. 2015. "Preferensi Pedagang Pasar Tradisional Terhadap Sumber Permodalan (Studi Pada Pedagang Pasar Merjosari Kecamatan Lowokwaru Kota Malang)." Jurnal Ilmiah Mahasiswa FEB 3 (1).

PINBUK. 2004. Manajemen Operasional Baitul Maal wat Tamwil. Jakarta: PINBUK Press.

Ridwan, Ahmad Hassan. 2004. BMT \& Bank Islam: Instrumen Lembaga Keuangan Syariah. Bandung: Pustaka Bani Quraisy.

Simamora, Elvidaris. 2014. Rentenir Akan Tumbuh Pesat. Accessed Juni 8, 2016.

Sri Murwanti dan Muhammad Sholahuddin. 2013. "Peran Keuangan Lembaga Mikro Syariah Untuk Usaha Mikro di Wonogiri." Seminar Nasional Peran Perbankan Syariah dalam Penguatan Kapasitas UMKM Menuju Kemandirian Ekonomi Nasional. Universitas Muhammadiyah Surakarta.

Yovita, Toti Indrawati dan Indri. 2014. "Analisis Sumber Modal Pedagang Pasar Tradisional di Kota Pekanbaru." Jurnal Ekonomi 22 (1): 1-8. 